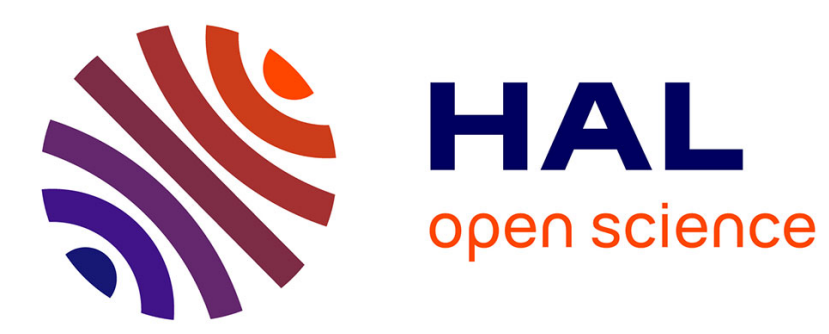

\title{
Nitrogen mineralisation in organic farming systems: a test of the NDICEA model
}

Chris Koopmans, Jan Bokhorst

\section{To cite this version:}

Chris Koopmans, Jan Bokhorst. Nitrogen mineralisation in organic farming systems: a test of the NDICEA model. Agronomie, 2002, 22 (7-8), pp.855-862. 10.1051/agro:2002046 . hal-00885982

\section{HAL Id: hal-00885982 \\ https://hal.science/hal-00885982}

Submitted on 1 Jan 2002

HAL is a multi-disciplinary open access archive for the deposit and dissemination of scientific research documents, whether they are published or not. The documents may come from teaching and research institutions in France or abroad, or from public or private research centers.
L'archive ouverte pluridisciplinaire HAL, est destinée au dépôt et à la diffusion de documents scientifiques de niveau recherche, publiés ou non, émanant des établissements d'enseignement et de recherche français ou étrangers, des laboratoires publics ou privés. 


\title{
Nitrogen mineralisation in organic farming systems: a test of the NDICEA model
}

\author{
Chris J. KOOPMANS* and Jan BOKHORST \\ Louis Bolk Institute, Hoofdstraat 24, 3972 LA Driebergen, The Netherlands \\ (Received 30 October 2001; revised 11 June 2002; accepted 25 June 2002)
}

\begin{abstract}
The validation of the carbon and nitrogen model NDICEA (Nitrogen Dynamics in Crop rotations in Ecological Agriculture) is presented. The model allows one to estimate how crop rotations and manure applications affect the amount of mineral nitrogen in different phases of a crop rotation. The model was tested on 8 organic farms and research sites. The model's performance was tested by means of visual performance and number of statistical measures. The results show that the model fits the observed mineral nitrogen for the top $30 \mathrm{~cm}$ of the soil with a modelling efficiency (ME) of 0.4 and a coefficient of determination $(r)$ of 0.65 . NDICEA is used to gain insight into the different sources of N mineralisation in the soil. Results show that the model NDICEA can be used to simulate sustainable farming systems at the field level using on-farm data and readily available climatic data. The model might therefore serve as a tool for evaluating the impact of the crop rotation and manure regime on long-term soil fertility levels and nitrogen leaching losses at the field level.
\end{abstract}

crop rotation / mineralisation / mineral nitrogen / modelling / organic farming

Résumé - Minéralisation d'azote en agriculture biologique : validation du modèle NDICEA. Cet article présente la validation du modèle NDICEA (Nitrogen dynamics in Ecological Agriculture). Ce modèle permet d'estimer l'impact de la rotation des cultures et de l'application d'engrais sur la quantité d'azote minéral aux différentes phases de la rotation. Il a été testé sur 8 exploitations biologiques et centres de recherches. La performance du modèle a été évaluée par des moyens visuels et un certain nombre de mesures statistiques. Les prévisions du modèle correspondent aux quantités d'azote minéral observées dans les 30 premiers centimètres du sol, avec une efficience de 0,4 et un coefficient de détermination de 0,65. NDICEA permet donc la compréhension des différentes sources de minéralisation d'azote dans le sol. Les résultats montrent que le modèle peut permettre de simuler des systèmes de production durables à l'échelle des parcelles en utilisant des données de la ferme en question et des données climatiques. Il pourra alors servir comme outil d'évaluation de l'impact de la rotation et des doses d'engrais sur la fertilité à long terme des sols et sur les pertes par lixiviation d'azote à l'échelle des parcelles.

rotation / minéralisation /azote minéral / modèle / agriculture biologique

\section{INTRODUCTION}

For sustainable and organic farmers who minimise chemical inputs it is important to have healthy soil with a good structure that can provide crops with necessary nutrients, suppress soil borne pathogens and keep soil moisture available to plants $[14,17]$.

In our current agricultural practices, soil fertility can be destroyed by rotations that focus on cash crops, leaving little room for soil-building crops [1]. Organic matter is often considered the key to achieving soil quality and health [4]. Carbon and nitrogen cycling through organic matter can improve soil fertility while reducing the negative environmental impact [6]. Alternative agricultural practices focusing on diversity in crop rotations have been shown to retain soil carbon and nitrogen $[6,21]$ with important implications for sustained production and environmental quality, by minimising losses of nitrate in agricultural drainage waters [7].

Researchers have tried since the 1970s to develop several mathematical and computer simulation models to describe $\mathrm{N}$ and $\mathrm{C}$ cycling through farming systems $[10,18-20]$. Although these models play an important role in research and policy scenarios, their complexity and input requirements have limited their practical value for sustainable farmers. A

Communicated by Sylvie Recous (Laon, France), Bernard Nicolardot (Reims, France)

* Correspondence and reprints

c.koopmans@louisbolk.nl 
significant contribution can be expected, however, from these models through farmer-focused systems. Although soils have an inherent quality within the constraints of climatic and ecosystem conditions, the ultimate determinant of soil quality and health are the farmers [5].

While current agricultural and environmental expectations can be met only via careful soil management, not only is there little recognition of the need to understand the nitrogen and organic matter dynamics in the soil, but traditional recommendations with regard to fertilisation and the design of crop rotations are no longer sufficient to meet the needs of organic farmers using complex rotations and practices. There is a need to understand these complex systems [17] that include the use of green manures, and solid and liquid animal manure.

To adjust crop rotations and compost or manure management to the specifics of each organic farm, site and soil, we have to quantify the contributions made by soil organic matter, compost and crop residues to the nitrogen availability of crops in rotation. The resulting model might be a tool for evaluating the impact of the crop rotation and manure regime on long-term soil organic matter levels and on the environmental quality indicated by nitrogen leaching losses.

In this paper we present the testing of a simple and user-friendly carbon and nitrogen model that would allow one to estimate how crop rotations and manure applications affect the amount of mineral nitrogen in the soil and how much nitrogen becomes available in the soil in different phases of a crop rotation. The model is meant to be a planning tool for farmers to design sustainable farming systems and to gain insight into whether their management practices are likely to maintain, improve, or degrade soil fertility.

\section{MATERIALS AND METHODS}

\subsection{The NDICEA model}

The NDICEA (Nitrogen Dynamics In Crop rotation in Ecological Agriculture) model is a dynamic, process-based model that calculates nitrogen and organic matter balances during a crop rotation [11]. The model consists of four major modules: the water balance, the organic matter balance, crop growth and nitrogen balance (Fig. 1). NDICEA has a time step of one week and was written in Pascal. The model runs in a Windows environment.

NDICEA differentiates the soil profile of the root zone into two layers, namely the top layer $(0-30 \mathrm{~cm})$ and sub-layer $(30-60 \mathrm{~cm})$. The top layer is the layer where mixing of the soil takes place through cultivation. Rooting of the crops depends on the type of crop, but was limited in our simulations to a maximum of $60 \mathrm{~cm}$. Manure and fertiliser additions are applied to the upper soil layer and are mixed into this layer. Storage of water and nutrients can also take place in the sub-layer if leaching occurs from the upper layer. In general, the partitioning into these two layers seems to be sufficient to represent systems that were described with the model $[11,13]$.

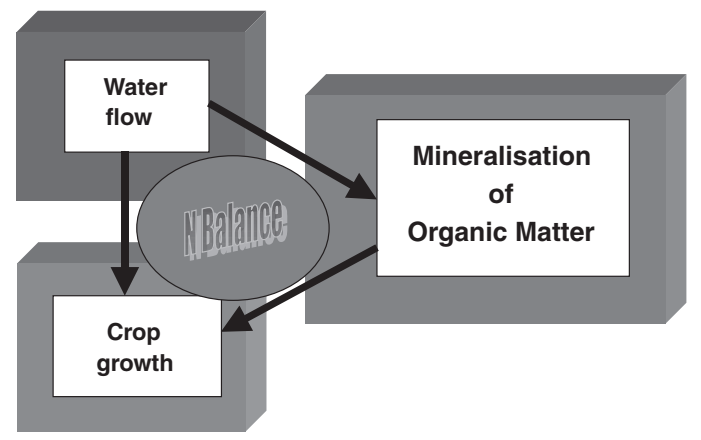

Figure 1. NDICEA is a simple, easy-to-apply two-layer model with a time-step of one week. The model integrates sub-models for the mineralisation of soil-bound organic matter, and for water balance and crop growth.

The water balance of the model depends on soil texture and is calculated from the water balance of each layer in the soil based on actual rainfall, irrigation and evaporation. This results in leaching or capillary rise in the soil [11]. Inorganic nitrogen is transported with the water down the soil profile, depending on a nitrogen leaching factor. Nitrogen that leaches below the rooting depth is considered lost.

The core of the model is the decomposition module in which the mineralisation process is described. Mineralisation is calculated for each successive application of organic matter, and according to the type and quantity of that organic matter. For each type of organic matter the $\mathrm{C}: \mathrm{N}$ ratio and the apparent initial age (ranging from 1 for green matter to 24 years for soil organic matter) according to Janssen [8] are used as input. Corrections are applied for soil temperature, soil moisture, texture and $\mathrm{pH}$ [11]. The undecomposed part of the organic matter contributes to the soil organic matter pool. The quantity of soil organic matter in the model is based on an initial soil analysis. The organic matter in NDICEA is distributed among three pools starting with $5000 \mathrm{~kg}$ organic matter in the young pool (initial age of 3.4 years) and $2000 \mathrm{~kg}$ in the fresh pool (initial age of 1.8 years). All other organic matter is distributed into the old organic matter with an initial age of 22.5 years. For initialisation we ran the model for a full rotation cycle at each farm, taking into account equilibrium in the young and fresh pools. $\mathrm{N}$ mineralisation is calculated based on the assimilation/dissimilation ratio of the soil organisms, the carbon/nitrogen ratio of soil organisms, the type of substrate and the rate of organic matter decomposition.

The nitrogen balance is calculated from the crop growth module and the water and organic matter balances. The balance is calculated based on the initial amount of $\mathrm{N}$ in a certain layer and the net amount accumulated in a certain week. The net weekly accumulation is the difference between total $\mathrm{N}$ input and total $\mathrm{N}$ output. The nitrogen balance includes $\mathrm{N}$ input fluxes such as mineralisation, atmospheric deposition, denitrification, fertiliser application, fixation and $\mathrm{N}$ input through capillary rise, and $\mathrm{N}$ outputs such as crop uptake, leaching and denitrification [11]. $\mathrm{NH}_{4}$ volatilisation and 
Table I. Input data for the NDICEA model.

\begin{tabular}{ll}
\hline Field & Input \\
\hline Environment & temperature $\left({ }^{\circ} \mathrm{C}\right)$, rainfall $(\mathrm{mm})$, evapotranspiration $(\mathrm{mm})$ \\
Soil & texture, organic matter $(\%), \mathrm{pH}$, groundwater table (time and depth of highest and lowest levels) \\
Crops & yield $(\mathrm{kg})$, dry matter $\left(\mathrm{kg} \cdot \mathrm{ha}{ }^{-1}\right)$, nitrogen conc. $(\%)$ \\
& date of sowing, full cover, ripening, harvest (week) \\
Organic manure & application rate $\left(\mathrm{kg}^{-h^{-1}}\right)$, dry matter $(\%)$, organic matter $(\%), \mathrm{N}$ conc. $(\%)$ \\
\hline
\end{tabular}

water logging are not part of the model. Nitrogen fluxes in the soil are associated with the water fluxes. $\mathrm{N}$ leaching is based on an excess of water, the amount of mineral $\mathrm{N}$ in the soil and soil physical properties. It is estimated to be the sum of matrix outflow and bypass flux of nitrogen. Denitrification is calculated in the model as a potential denitrification, corrected for soil moisture and mineral $\mathrm{N}$ content in the soil according to Bradbury [3].

Crop uptake depends on crop-dependent uptake curves and actual yields. Crop nitrogen uptake is calculated based on nitrogen concentration in the crops (product, residues and roots), water uptake, soil moisture content and $\mathrm{N}$ concentration in the soil water. $\mathrm{N}$ fixation of legumes is estimated from the potential $\mathrm{N}$-fixation and the mineral $\mathrm{N}$ content of the soil. Water uptake by a crop is governed by evaporative demand, crop morphology, ground coverage and soil moisture content $[11,22]$.

Necessary input data for the model are summarised in Table I. Major outputs of the model consist of expected mineral nitrogen in the soil layers, $\mathrm{N}$ uptake of the crops and levels of organic matter in the soil.

The model was evaluated for arable land $[2,12,13]$, vegetable production [13] and greenhouse vegetable production [16]. A sensitivity analysis of the model showed that the annual mineralisation is sensitive to the $\mathrm{C} / \mathrm{N}$ ratio of the soil micro-organisms and the nitrogen content of the applied soil organic matter, and somewhat sensitive to the assimilation/dissimilation ratio of the micro-organisms [11]. Annual leaching losses are sensitive to $\mathrm{N}$ mineralisation and the factors influencing that mineralisation, as well as the distribution and water uptake from the top and lower layers in the soil.

\subsection{Site description}

We monitored inorganic nitrogen levels at 8 organic farms and research locations located throughout the Netherlands. Another 38 farms were monitored less intensively, and some estimates were made of nitrogen concentrations in crops. Results are presented from the intensively monitored farms.

These farms vary with regard to soil type, crop rotation and manure applications (Tabs. II and III). At 14-day intervals throughout the year, the inorganic nitrogen levels in the upper soil $(0-30$ and $30-60 \mathrm{~cm})$ were monitored on two fields at each farm. Ammonium $\left(\mathrm{NH}_{4}-\mathrm{N}\right)$ and nitrate $\left(\mathrm{NO}_{3}-\mathrm{N}\right)$ nitrogen were determined colorimetrically in a $0.01 \mathrm{M} \mathrm{CaCl}_{2}$ extract on an autoanalyser. To determine changes that might impact crop growth and mineralisation in the soil, the soil-structure and rooting depth in each field were described at regular intervals (i.e. six times a year). Crop growth and yields were determined from a minimum of two subplots $\left(10 \mathrm{~m}^{2}\right.$ each $)$ within each field. Plant material was dried at $70{ }^{\circ} \mathrm{C}$ for 72 hours, and total-N (\%) determined. All animal manure applications were registered, and samples analysed for dry matter, organic matter, $\mathrm{NH}_{4}-\mathrm{N}$ and total-N.

Model input for the climatic conditions was obtained from local weather stations. Figure 2 shows the climatic conditions for the stations located close to farms 2 and 6, respectively, evaluated in more detail in this study.

\subsection{Model performance}

Since the focus of our study was to test the NDICEA model, no parameter fitting procedure was used to optimise model performance. Our data set for this test was a new data

Table II. Summary of soil and crop rotation characteristics at a selection of the farms.

\begin{tabular}{llccll}
\hline Farm & Soil type & $\begin{array}{c}\text { Organic matter } \\
(\%)\end{array}$ & $\begin{array}{c}\mathrm{pH} \\
(\mathrm{KCl})\end{array}$ & $\begin{array}{c}\text { Total N } \\
\mathrm{g} \cdot \mathrm{kg}^{-1}\end{array}$ & Crop rotation \\
\hline 1 & sand & 1.7 & 6.8 & 0.8 & tulip-w. radish/daffodil-y. mustard/crocus/grass-clover/lily/grass-clover \\
2 & loamy sand & 2.6 & 6.2 & 0.9 & lettuce/chin. cabbage/leek/bean-marigold/carrots/triticale-clover \\
3 & loamy sand & 3 & 5.3 & 1.4 & intensive mixed vegetables \\
4 & loamy sand & 3.6 & 5.2 & 0.8 & potato/oats-clover/sugarb./hemp/carrot/barley-clover \\
5 & sandy loam & 2.9 & 5.8 & 1.2 & potato-oats/cabbage/sp. barley-oats/sugarb./oats-oats \\
6 & loam & 4.4 & 7.2 & 1.7 & corn-silage/pumpkin/carrot/broccoli/french-bean \\
7 & loam & 4.8 & 7.5 & 1.8 & maize, carrots, spinach, beets, beans and onions \\
8 & clay loam & 5 & 7.3 & 2 & s.wheat-clover/potato/lettuce/grass-clover/br. sprout/fennel \\
\hline
\end{tabular}


Table III. Summary of crops and fertilisers at farms Nos. 2 and 6.

\begin{tabular}{|c|c|c|c|c|c|c|c|}
\hline Farm & Year & Crop & $\begin{array}{l}\text { Time } \\
\text { (week) }\end{array}$ & Fertiliser & $\begin{array}{l}\text { Amount } \\
\text { (per ha) }\end{array}$ & $\begin{array}{c}\text { Dry matter } \\
(\%)\end{array}$ & $\begin{array}{c}\mathrm{N} \\
(\% \text { of dry matter) }\end{array}$ \\
\hline \multirow[t]{6}{*}{2} & 1997 & Lettuce I & 11 & Cattle FYM & 25 ton & 30.8 & 1.7 \\
\hline & 1997 & Lettuce II & 14 & Bloodmeal & $285 \mathrm{~kg}$ & 90 & 12.0 \\
\hline & & & 16 & Bloodmeal & $292 \mathrm{~kg}$ & 90 & 12.0 \\
\hline & 1998 & Chin. cabbage II & & & & & \\
\hline & 2000 & French bean & 15 & Cattle slurry & 20 ton & 9,5 & 4.6 \\
\hline & 2000 & Marigold & & & & & \\
\hline \multirow[t]{3}{*}{6} & 1997 & Corn silage & 47 & Cattle FYM & 35 ton & 30,8 & 1.7 \\
\hline & 1998 & Pumpkin & 20 & Cattle slurry & 15 ton & 9.5 & 4.6 \\
\hline & 1999 & Carrot & & & & & \\
\hline
\end{tabular}
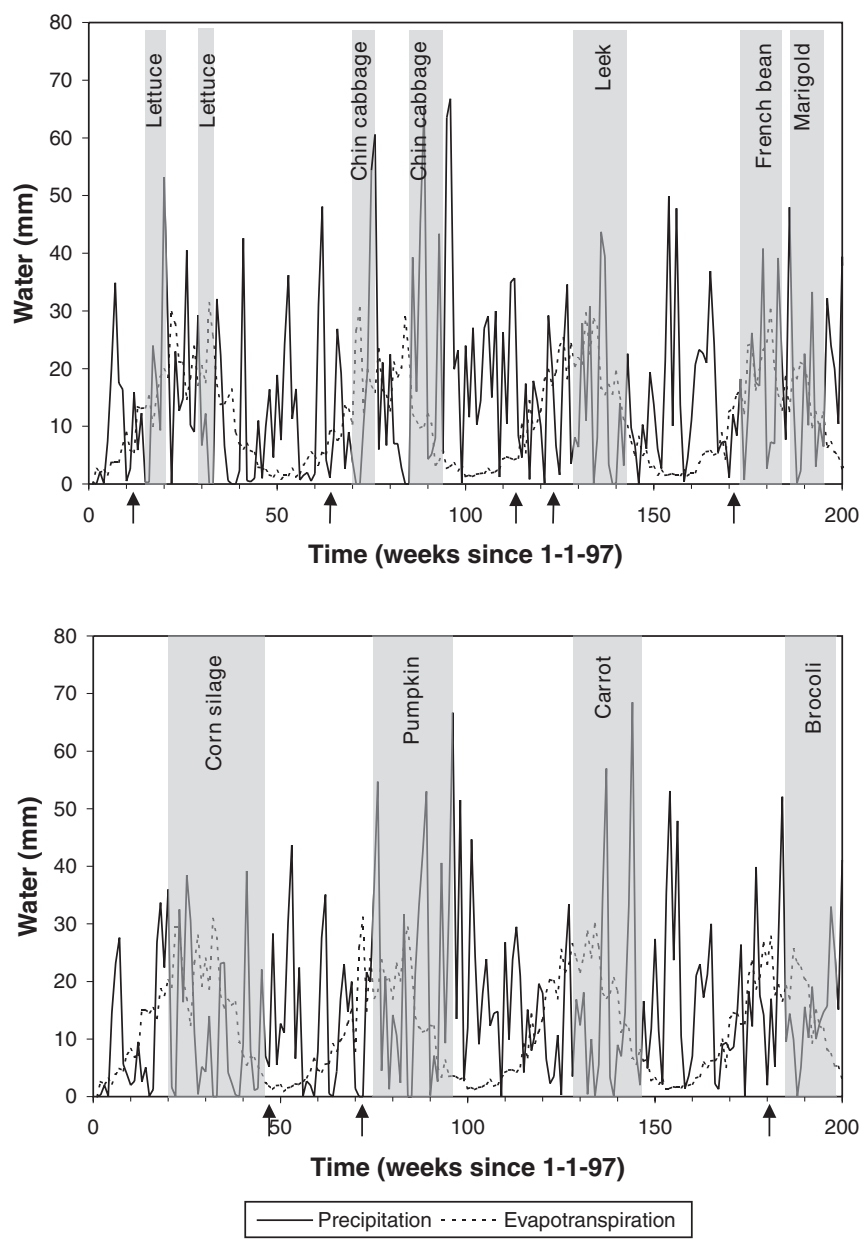

Figure 2. Climatic conditions in the years 1997 to 2000 for farms No. 2 (top) and No. 6 (bottom). Gray bars indicate the growing period of a crop, arrows the time of manure application. set and independent from earlier data sets used for calibrating the model.

The model's performance was evaluated visually as well as by statistical measures developed by Janssen and Heuberger [9]. These statistical measures should be handled with care as they only reflect the model's performance to a certain degree. With the Average error (AE), simulations and observations are compared on an average level (e.g. over the whole time span). The bias between average values of model simulations and observations is expressed by the AE: a positive $\mathrm{AE}$ indicates that model simulations overestimate the observed values. The Normalised Root Mean Square Error (NRMSE) describes a coefficient of variation of the discrepancies between simulated and observed values around the mean of the observations. The Model Efficiency (ME) quantifies the improvement of the model over a simple model with no mechanistic interpretation given by the mean of the observations.

\section{RESULTS}

\subsection{Effects of the year}

Precipitation and evaporation were used as input to simulate the nitrate-N level in the soil shown in Figure 3. The grey bars indicate the time crops are standing in the field. The model is able to follow the dynamics of nitrogen in the upper $30 \mathrm{~cm}$ in these organic rotations on the different soil types. Visually, the simulated mineral $\mathrm{N}$ levels in the soil follow the observed values closely. In general, NDICEA accurately predicted the postharvest nitrate in the fields, but it tended to underestimate high levels of $\mathrm{NO}_{3}-\mathrm{N}$ found directly after applications of the organic manures and directly before planting.

The predicted and observed decrease in nitrate in the profile is consistent with precipitation during the year (Fig. 2). 

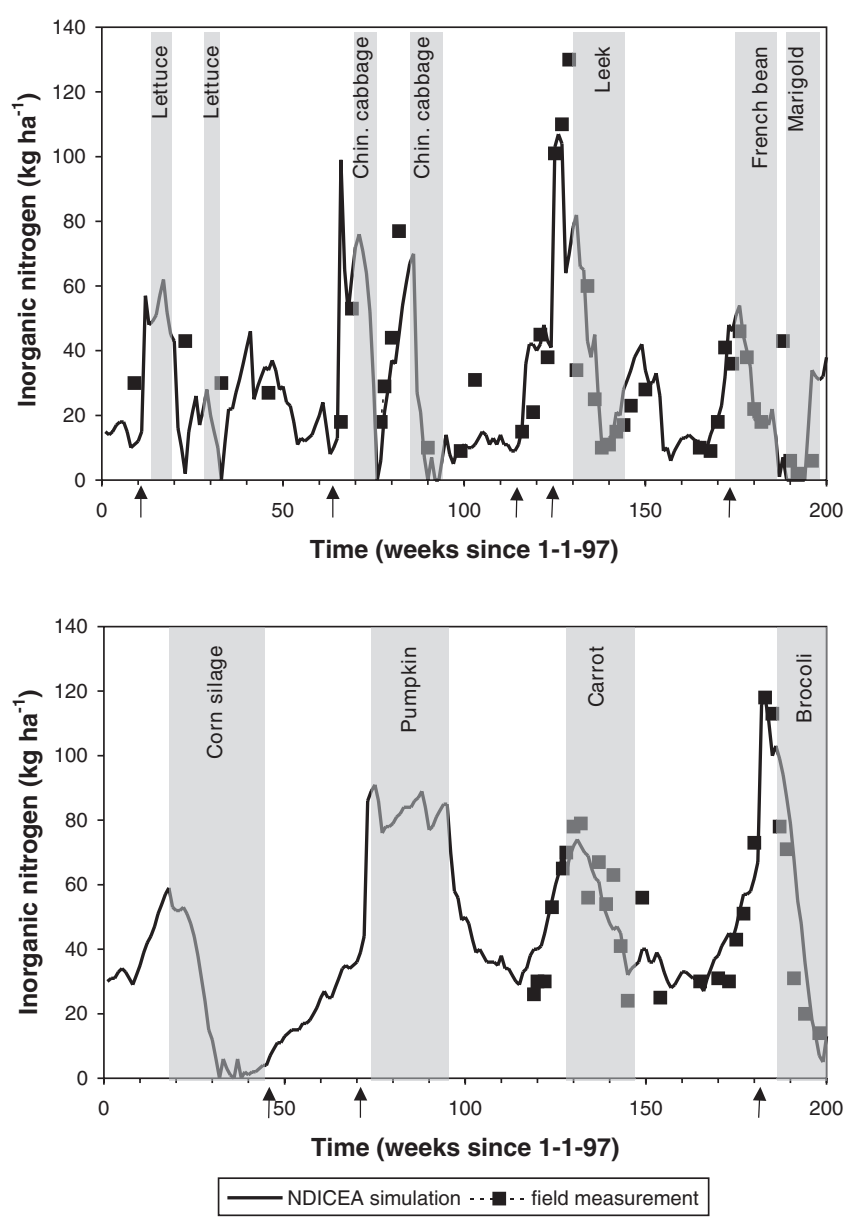

Figure 3. Simulated (line) and observed inorganic nitrogen levels (symbols) in the upper soil $(0-30 \mathrm{~cm})$ at farms No. 2 with an intensive vegetable rotation on a loamy sand (top) and a field on farm No. 6 on a sandy loam (bottom). Gray bars indicate the growing period of a crop, arrows the time of manure application.

This generally results in peaks of nitrate leaching in the autumn, but also during the season in the case of heavy rain events. Figure 4 shows the nitrate leaching below the rooting zone $(60 \mathrm{~cm})$ as simulated by the model for the fields at farms 2 and 6 . The intensive vegetable rotation and the sandy soil of farm 2 tended to result in high leaching losses at this farm. The loamy soil and limited fertiliser use of farm 6 resulted in much lower leaching losses. Mineralisation, indicated by the dotted line, also shows peak values. These peaks coincide with the application of an organic fertiliser in which the applied $\mathrm{NH}_{4}-\mathrm{N}$ shows up as a rapid mineralisation during the time of application of the fertiliser.

\subsection{Model performance}

We tested the model by comparing the observed mineral nitrogen levels found in the soil at the eight sites with the simulated mineral nitrogen levels (Fig. 5). The results show that the model did a reasonable job of fitting the observed data in
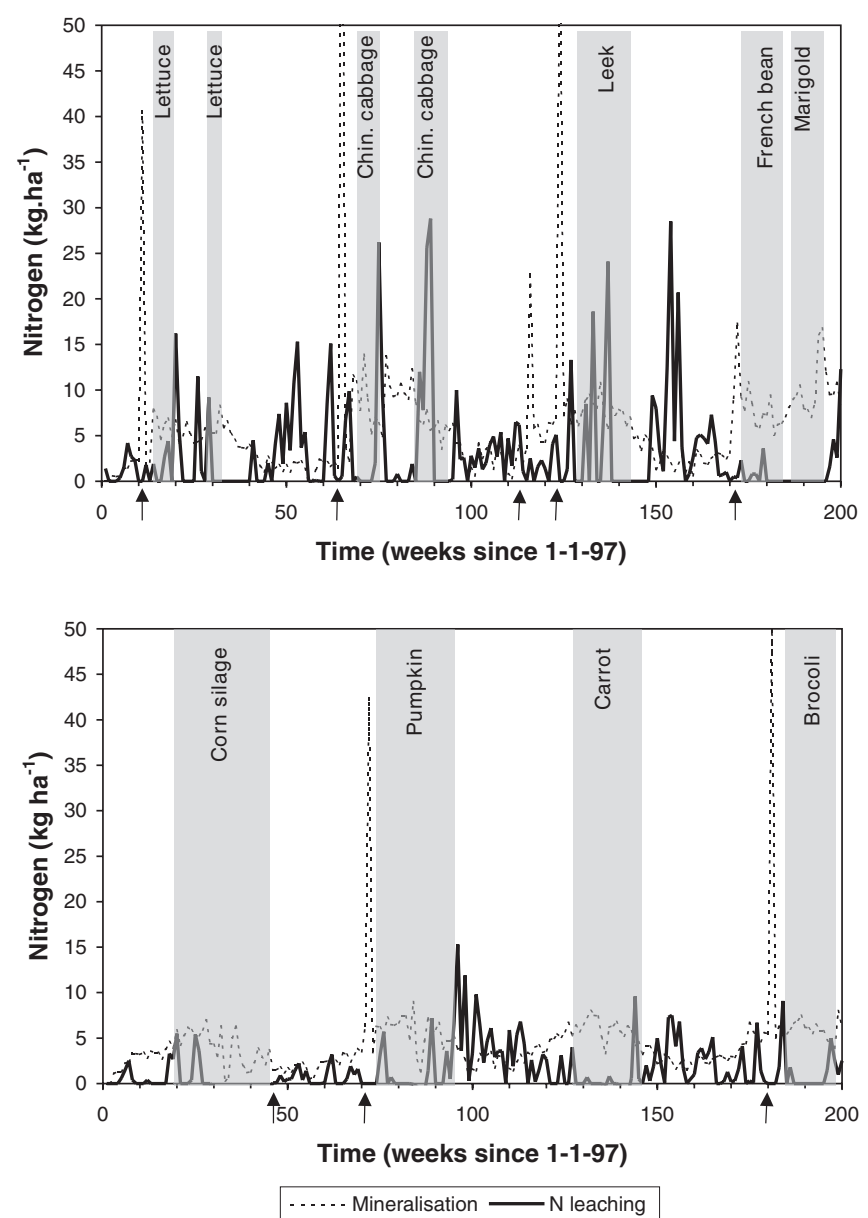

Figure 4. Running the model indicates nitrogen mineralisation and leaching during different phases of the crop rotation. Examples of farms 2 (top) and 6 (bottom). The simulated mineralisation peaks represent an inorganic fraction in the manure applied.

the top $30 \mathrm{~cm}$. With the quantitative techniques, it is possible to express the agreement between model and data numerically (Tab. IV). The AE indicates that the bias between average values of model predictions and observation is small for the topsoil. At mineral $\mathrm{N}$ levels of $150 \mathrm{~kg} \mathrm{~N}$ per ha and more, the model underestimated the mineral $\mathrm{N}$ levels found in the soil. The NRMS indicating the coefficient of variation around the mean of the observations is limited. A ME of 0.4 shows a model performance for the upper soil which is much better than was found for the sub-layer (ME of 0.1). The results show that the model underestimates the mineral $\mathrm{N}$ levels found in the sub-layer (AE is negative) and improvements are necessary (e.g. site-specific calibration might be necessary in this case).

\section{3. $\mathrm{N}$ mineralisation}

An important advantage of using a simulation model is the insight gained into the different sources of mineralised $\mathrm{N}$. 
Table IV. Performance statistics of the model NDICEA based on simulations of 8 sites for the years 1999 and 2000.

\begin{tabular}{lcr}
\hline & Topsoil mineral N kg N$\cdot \mathrm{ha}^{-1}$ & ${\text { Subsoil mineral N kg N} \cdot \mathrm{ha}^{-1}}^{-1}$ \\
\hline Mean of observations (MO) & 42.1 & 40.7 \\
Average error (AE) & 1 & -14.8 \\
Normalised root mean square error (NRMSE) & 0.9 & 1.4 \\
Modelling efficiency (ME) & 0.4 & 0.1 \\
Coefficient of determination & 0.65 & 0.47 \\
Number of data & 547 & 482 \\
\hline
\end{tabular}
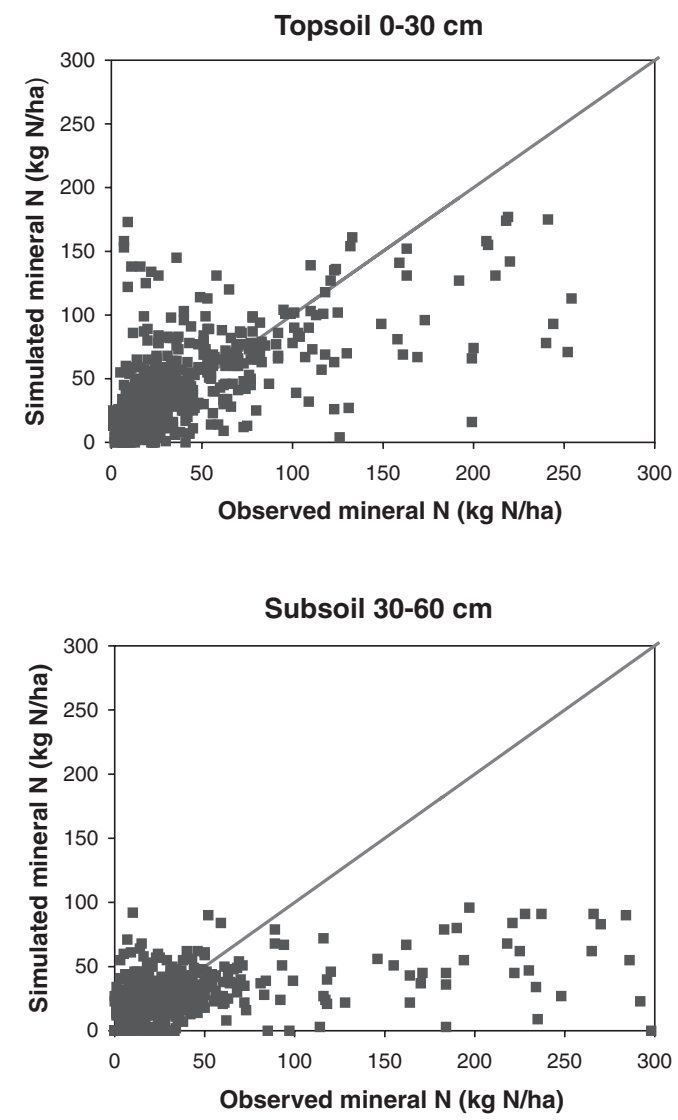

Figure 5. Performance of the model NDICEA showing simulated inorganic nitrogen levels in the soil $(0-30 \mathrm{~cm})$ plotted against measured inorganic N levels from all 16 fields from 1997 to 2000.

NDICEA was used to identify these sources for the whole crop rotation at these farms. Mineral nitrogen which becomes available during the season is derived from several sources such as soil organic matter, crop residues and organic fertilisers used on these farms (Fig. 6).

The simulations show that, due mainly to the levels of organic matter in the soil, sources of nitrogen differ quite a bit from farm to farm. The importance of nitrogen mineralisation out of the initial soil organic matter becomes apparent and makes up from $25 \%$ to almost $60 \%$ of the total nitrogen which becomes available during the season. Also, the amount of residues accounting for nitrogen availability differ from farm to

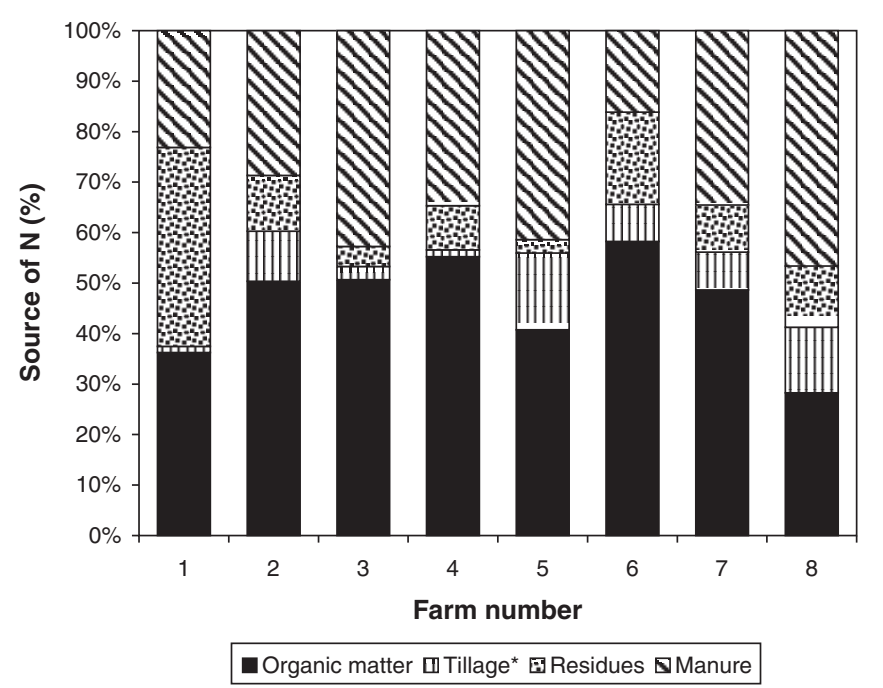

Figure 6. Nitrogen mineralisation from different sources of organic matter as estimated with the NDICEA model for farm number 1 to 8 .

farm and, especially if a green manure is used, the contribution may be high (see farms 1 and 6 in Fig. 6).

The temporal variations in mineralisation found, accompanying leaching losses of nitrogen (Fig. 4), is important management information for the farmer so as to be able to synchronise nitrogen mineralisation with crop needs and to reduce nitrogen leaching losses.

\section{DISCUSSION}

\subsection{Testing}

If models are to be effective for evaluating alternative management strategies, they need to reproduce accurately the seasonal variations of nitrogen found in the soil and the long-term changes in soil properties. Validation of models' performances against observations from farm fields is a way of testing whether the models are adequate [9], but also if model input is in accordance with data input that can reasonably be obtained by the users in the future: extension and well educated farmers.

We used measured soil organic $\mathrm{C}$ and $\mathrm{N}$ for initialisation of the model and distributed soil organic $\mathrm{C}$ between the three 
pools of organic matter distinguished in the model based on the land-use history of the fields. The time frame of the monitoring and limited changes in total soil organic $\mathrm{C}$ and $\mathrm{N}$ during that time is, however, a major limitation of the data set. NDICEA captured the changes in nitrate nitrogen in the soil during crop rotations reasonably well. The model was developed to simulate these changes [2] and it performed this function well. As a tool, the model seems to be able to distinguish between the different sources of mineralisation [13].

Other features such as the impact of management strategies on changes in soil organic matter (e.g. changes in soil fertility), which is important management information for organic farmers [6, 14], need further testing, based on long-term studies. Due to the limited performance of the model in predicting nitrogen levels lower in the soil, care should be taken in using the model for predicting nitrogen leaching losses. This performance might be due to an unaccounted mineralisation potential in this lower sub-layer. Discrepancies between simulations and observation in the top layer occur in heavier soils and might be due to an unaccounted compaction of the soil during certain periods of the year, which might slow down mineralisation or speed it up after cultivation.

\subsection{Timing of activities}

Nitrate levels in the soil in excess of crop needs are frequently observed on organic farms [13], thereby creating the potential for leaching. With the model, organic production has the potential to be attuned to each specific farm, site and soil. Timing manure applications and the use of cover crops seems essential to the management of nitrogen leaching losses in these organic farming systems.

For organic farming systems, the challenge is to find more specific manuring practices that provide crops with sufficient nutrients while simultaneously reducing nitrogen leaching losses to a minimum and maintaining long-term soil fertility [13].

\subsection{Mineralisation}

The model could serve as a tool to guide the mineralisation process at the field level. The selection, timing and appropriate use of green manure crops and fertilisers determine not only when nitrogen becomes available in the soil, but also what happens to that nitrogen (i.e. uptake by plants, or loss via leaching) [2].

We compared the differences between a dynamic approach using the simulation model NDICEA and the more traditional, static methods of calculating the effects of manure and green manures [15]. The results of this comparison showed that in general the model NDICEA calculates lower $\mathrm{N}$ release for solid manures than the traditional ways of calculation. In addition, the release is more dynamic with $\mathrm{N}$ release depending on the environmental conditions, crop growth and length of growth. This becomes even more pronounced for slurry in which $\mathrm{N}$ release varies from $63 \%$ for the slurry, applied to sugar beet compared with only $38 \% \mathrm{~N}$ release during the growth of a leek crop. These results, however, do not say anything about whether the $\mathrm{N}$ is actually taken up by the crop.

The soil-specific mineralisation of nitrogen is largely unaccounted for in present fertiliser recommendation schemes [15]. This may result in an overabundance of nitrogen in the soil, and potentially high nitrogen leaching losses. However, there is as yet no direct, practical and easy-to-use method for measuring nitrogen mineralisation in the soil. The NDICEA simulation model serves as a useful tool for gaining insight into nitrogen and organic matter dynamics in organic farming systems. It can be used to obtain site-specific nitrogen mineralisation levels. In future, it should be combined with direct measurements of nitrogen mineralisation and observations of soil structure. These results also show the importance of developing easy-to-use methods for the routine measurement of nitrogen mineralisation.

\subsection{Simple model and management aid}

The process of developing and applying the NDICEA model in the last couple of years has shown that a relatively simple model can be developed and tested using data from the farm level $[2,13]$.

The simple models can represent most of the dynamics taking place at the cropping system level and also describe dynamics considered in more complex models. The results from this paper show that the NDICEA can be used successfully to simulate the farming systems at the field level using readily available data (weekly climatic data, soil data and crop yields). The results show that we should continue to develop these models and test them using data gained from farming practice. The model might be used more and more to solve applied management problems at the farming level.

Analysing different management strategies requires further management decision opportunities and suggestions for the farmer or farm adviser; for instance, about when to apply the organic fertiliser or when to plant. Important information is, however, readily available for the user, such as the effect of weather conditions (e.g. What caused a high or low nitrogen availability in spring? Was it due to the weather conditions or the choice of organic fertiliser and what organic fertiliser could be used best?). Further development of NDICEA is an ongoing activity which should improve the capabilities of the model, its user-friendliness and its performance in the future.

Because, in the long run, soil fertility is of paramount importance to our organic farming systems $[6,17,21]$, it is essential for the design and maintenance of these systems that we gain the greatest possible insight into soil fertility at the process level.

Acknowledgements: The authors would like to thank G. Oomen and F. Habets (Wageningen Agricultural University) for their work in developing the model. We are also very grateful to F. Wijnands, P. van Asperen, P. Koot, J. Rovers (Wageningen University and Research Centre) and the farmers for access to the field experiments and farm fields.

This research was financially supported by the Dutch Ministry of Agriculture, project No. 3201304. 


\section{REFERENCES}

[1] Aref S., Wander M.M., Long-term trends of corn yield and soil organic matter in different crop sequences and soil fertility treatments on the Morrow Plots, Adv. Agron. 62 (1998) 153-197.

[2 ] Bokhorst J.G., Oomen G.J.M., Fine-tuning of N fertilization in biological agriculture using the N-DICEA model, Meststoffen 1997/1998, pp. 40-46.

[3] Bradbury N.J., Whitmore A.P., Hart P.B.S., Jenkinson D.S., Modelling the fate of nitrogen in crop and soil in the years following application of ${ }^{15} \mathrm{~N}$-labelled fertilizer to winter wheat, J. Agric. Sci. 121 (1993) 363-379.

[4] Doran J.W., Coleman D.C., Bezdicek D.F., Stewart B.A. (Eds.), Defining Soil Quality for a Sustainable Environment, SSSA Special Publication Number 35, Madison, Wisconsin, 1994.

[5] Doran J., Liebig M., Santana D.P., Soil health and global sustainability, in: Proceedings of the 16th World Congress of Soil Science, Montpellier, France, August 20-26, 1998.

[6] Drinkwater L.E., Wagoner P., Sarrantonio M., Legume-based cropping systems have reduced carbon and nitrogen losses, Nature 396 (1998) 262-265.

[7] Goldstein W.A., Scully M.J., Kohl D.H., Shearer G., Impact of agricultural management on nitrate concentrations in drainage waters, Am. J. Altern. Agric. 13 (1998) 105-110.

[8] Janssen B.H., A simple method for calculating decomposition and accumulation of 'young' soil organic matter, Plant and Soil 76 (1984) 297304.

[9] Janssen P.H.M., Heuberger P.S.C., Calibration of process-oriented models, Ecol. Model. 83 (1995) 55-66.

[10] Jenkinson D.S., Raynor J.H., The turnover of soil organic matter in some of the Rothamsted classical experiments, Soil Sci. 123 (1977) 298-305.

[11] Habets A.S.J., Oomen G.J.M., Modelling nitrogen dynamics in crop rotations in ecological agriculture, in: Neeteson J.J., Hassink J. (Eds.), Nitrogen mineralisation in agricultural soils: Proceedings symposium at the Institute for Soil Fertility Research, Haren NL, 19-20 April 1993, AB-DLO, Haren, The Netherlands, 1994, pp. 255-268.

[12] Kaul H.P., Sensitivity of crop growth models to rotation effects, especially to the pre-crop dependent variation of available soil mineral nitro- gen, MSc. thesis, Department of Theoretical Production Ecology, Wageningen University, The Netherlands, 1999, 140 p.

[13] Koopmans C.J., Bokhorst J., Optimising organic farming systems: nitrogen dynamics and long-term soil fertility in arable and vegetable production systems in the Netherlands, in: Alföldi T., Lockeretz W., Nigli U. (Eds.), IFOAM 2000-The World Grows Organic, Proceedings of the 13th International IFOAM Scientific Conference Basel 28 to 31 August 2000, Hochschulverlag AG an der ETH Zurich, 2000, pp. 69-72.

[14] Koopmans C.J., Goldstein W., Soil organic matter budgeting in sustainable farming, Michael Fields Agricultural Institute Bulletin No. 7, East Troy, WI, USA, 1998

[15] Koopmans C.J., Zwart K., Van rekenregel naar simulatiemodel: een vergelijking van hulpmiddelen om stikstofstromen in de bodem te voorspellen, Ekoland 4 (2001) 22-23.

[16] Koopmans C.J., Bloemhard C., Bokhorst J.G., Voogt W., Organic greenhouses and sustainability, in: Alföldi T., Lockeretz W., Nigli U. (Eds.), IFOAM 2000-The World Grows Organic, Proceedings of the 13th International IFOAM Scientific Conference Basel 28 to 31 August 2000, Hochschulverlag AG an der ETH Zurich, 2000, 212 p.

[17] Mäder P., Fliessbach A., Dubois D., Gunst L., Fried P., Niggli U., Soil fertility and biodiversity in organic farming, Science 296 (2002) 1694-1697.

[18] Parton W.J., Schimel D.S., Cole C.V., Ojima D.S., Analysis of factors controlling soil organic matter levels in Great Plains grasslands, Soil Sci. Soc. Am. J. 51 (1987) 1173-1179.

[19] Paustian K., Parton W.J., Persson J., Modeling soil organic matter in organic-amended and nitrogen fertilized long-term plots, Soil Sci. Soc. Am. J. 56 (1992) 476-488.

[20] Van Veen J.A., Paul E.A., Organic carbon dynamics in grassland soils: 1. Background information and computer simulation, Can. J. Soil Sci. 61 (1981) 185-201

[21] Wander M.M., Traina S.J., Stinner B.R., Peters S.E., Organic and conventional management effects on biologically active soil organic matter pools, Soil Sci. Soc. Am. J. 58 (1994) 1130-1139.

[22] Woli P.B., Nitrogen and organic matter balances as calculated by the target-oriented models 'QUADMOD ${ }^{\text {plus, }}$ and 'NDICEA' to evaluate crop rotations, MSc. thesis, Department of Theoretical Production Ecology, Wageningen University, The Netherlands, 2000, 140 p. 